\title{
Studi Komparasi Pemikiran Elly Risman dan Konsep Perkawinan Islam dalam Pola Ketahanan Keluarga untuk Mencegah Kenakalan Remaja
}

\author{
Ely Muawanah ${ }^{1}$ \\ ${ }^{1}$ Fakultas Syariah, IAIN Jember. E-mail: elymuawanah1@gmail.com
}

\begin{tabular}{|c|c|}
\hline Article & Abstract \\
\hline $\begin{array}{l}\text { How to cite: } \\
\text { Ely Muawanah, 'Studi } \\
\text { Komparasi Pemikiran } \\
\text { Elly Risman dan Konsep } \\
\text { Perkawinan Islam dalam } \\
\text { Pola Ketahanan Keluarga } \\
\text { untuk Mencegah } \\
\text { Kenakalan Remaja' (2020) } \\
\text { Vol. } 1 \text { No. } 2 \\
\text { Rechtenstudent Journal } \\
\text { Fakultas Syariah IAIN } \\
\text { Jember. } \\
\text { Histori artikel: } \\
\text { Submit } 2 \text { April 2020; } \\
\text { Diterima } 20 \text { Juli 2020; } \\
\text { Diterbitkan } 5 \text { Agustus } \\
\text { 2020. } \\
\text { ISSN: } \\
\text { 2723-0406 (media cetak) }\end{array}$ & 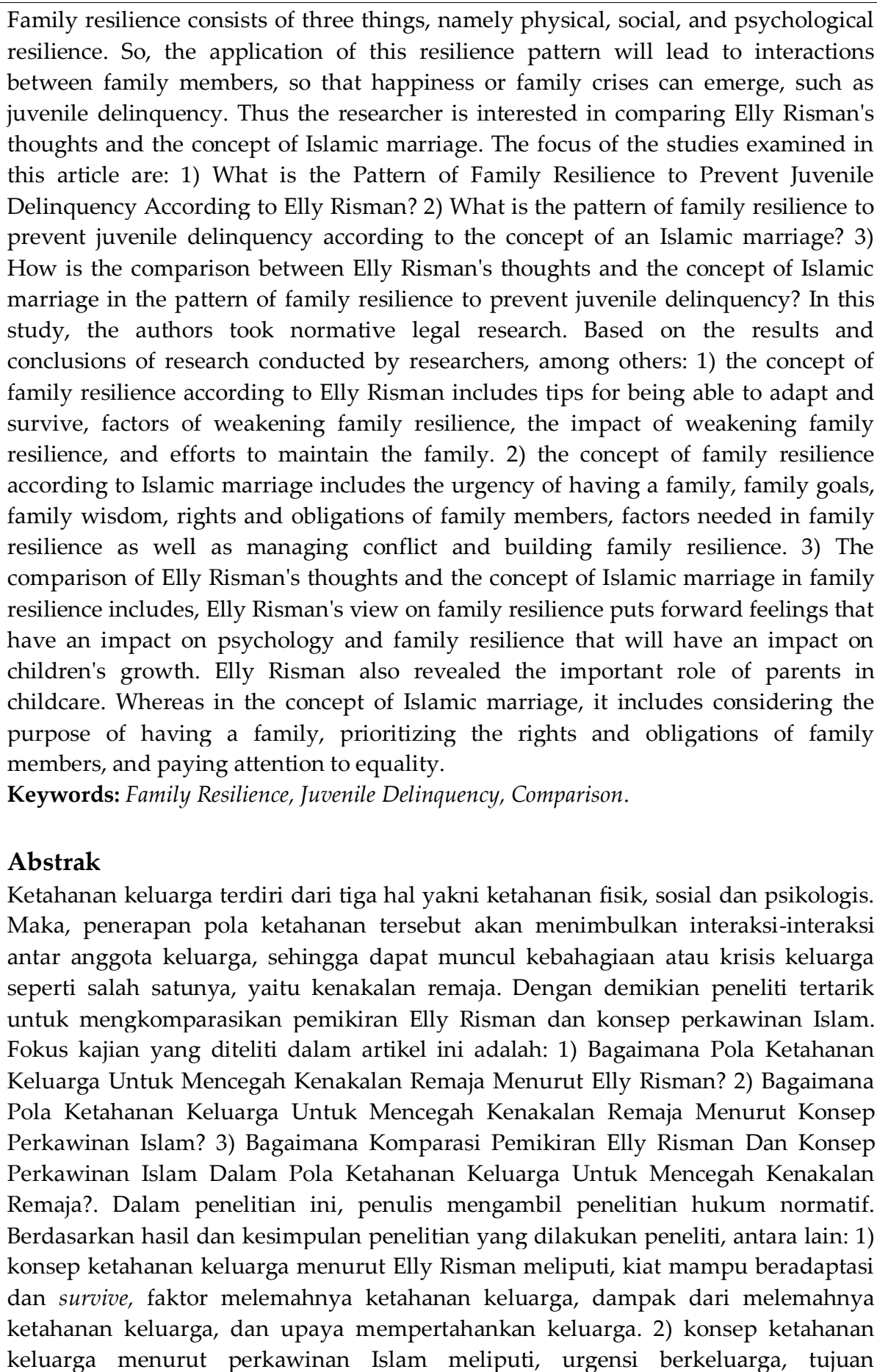 \\
\hline
\end{tabular}


berkeluarga, hikmah berkeluarga, hak dan kewajiban anggota keluarga, faktor yang diperlukan dalam ketahanan keluarga serta mengelola konflik dan membangun ketahanan keluarga. 3) Komparasi pemikiran Elly Risman dan Konsep Perkawinan Islam dalam ketahanan keluarga meliputi, pandangan Elly Risman dalam ketahanan keluarga mengedepankan perasaan yang berdampak pada psikisnya serta ketahanan keluarga yang akan berdampak pada pertumbuhan anak. Elly Risman juga mengungkapkan peran penting orang tua dalam pengasuhan anak. Sedangkan dalam konsep perkawinan Islam meliputi, mengingat tujuan berkeluarga, mengedepankan hak dan kewajiban anggota keluarga serta memperhatikan kesetaraan.

Kata Kunci: Ketahanan Keluarga, Kenakalan Remaja, Komparasi.

\section{Pendahuluan}

Rumah tangga atau keluarga dapat diartikan sebagai satu sistem keluarga yang berlandaskan keimanan dan ketaqwaan kepada Allah. Beramal șalih untuk meningkatkan potensi semua anggota, beramal șalih untuk keluarga, keluarga lain di sekitarnya, dan berwasiat atau berkomunikasi dengan cara bimbingan yang haq, kesabaran, dan penuh dengan kasih sayang. ${ }^{1}$ Sebagaimana firman Allah dalam QS. Ar-Rum ayat 21:

Artinya: Dan diantara tanda-tanda Kebesaran-Nya ialah dia ciptakan pasangan-pasangan untukmu dari jenismu sendiri, agar kamu cenderung dan merasa tentram kepadanya, dan dia menjadikan di antaramu rasa kasih dan sayang. Sungguh, pada yang demikian itu benar-benar terdapat tanda-tanda (kebesaran Allah) bagi kaum yang berfikir. ${ }^{2}$

Ayat ini mengamanatkan kepada umat manusia bahwa diciptakannya istri agar suami dapat membangun keluarga yang sakinah bersama pasangannya. Ketentraman dalam berkeluarga dapat tercapai apabila di antara keduanya terdapat kerja sama timbal balik yang serasi, selaras dan seimbang. Masing-masing individu harus bisa saling memahami serta menerima kelebihan dan kekurangan pasangannya.

Pola ketahanan keluarga adalah kemampuan keluarga dalam mengelola sumber daya dan masalah yang dihadapinya untuk memenuhi kebutuhan anggotanya. Ketahanan keluarga terdiri dari tiga hal yakni ketahanan fisik, sosial dan psikologis. Dalam perspektif ilmu psikologi, ketahanan keluarga dibangun berdasarkan perkembangan dari paradigma Competence-Based and Strength-oriented family untuk membantu memperoleh sebuah pemahaman tentang bagaimana keluarga menampilkan ketahanan ketika diuji dengan berbagai kesulitan. Keluarga juga menghadapi gangguan atau ancaman dari berbagai aspek kehidupan seperti: sosial, ekonomi dan lingkungan. Ali Imron berpendapat bahwa peran orang tua sangat penting dalam membentuk karakter serta kepribadian seorang anak ia juga menyatakan harus ada formula khusus untuk memantau kepribadian anak agar tidak mudah terjerumus ke dalam kenakalan remaja. Maka penerapan pola ketahanan tersebut akan menimbulkan interaksi-interaksi antar anggota keluarga, sehingga dapat muncul kebahagiaan atau krisis keluarga seperti salah satunya, yaitu kenakalan remaja. ${ }^{3}$

\footnotetext{
${ }^{1}$ Sofyan S Willis, Konseling Keluarga: Suatu Upaya Membantu Anggota Keluarga Memecahkan Masalah Komunikasi di dalam Sistem Keluarga (Bandung: Alfabeta, 2009), 170.

${ }^{2}$ Al-Qur'an, 30:21.

${ }^{3}$ Bayyinatul Muchtaromah, Pendidikan Reproduksi bagi Anak Menuju Akil Baligh (Malang: UIN Malang Press, 2008), 293.
} 


\section{Rumusan Masalah}

Adapun permasalahan yang diangkat menjadi pokok masalah sebagai berikut :

1. Bagaimana Pola Ketahanan Keluarga untuk Mencegah Kenakalan Remaja Menurut Pemikiran Elly Risman?

2. Bagaimana Pola Ketahanan Keluarga untuk Mencegah Kenakalan Remaja Menurut Konsep Perkawinan Islam?

3. Bagaimana Komparasi Pemikiran Elly Risman dan Konsep Perkawinan Islam dalam Pola Ketahanan Keluarga untuk Mencegah Kenakalan Remaja?

\section{Metode Penelitian}

Dalam penelitian ini penulis mengambil penelitian hukum normatif. Penelitian hukum normatif disebut juga penelitian hukum doktrinal. Pada penelitian hukum jenis ini, seringkali hukum dikonsepkan sebagai apa yang tertulis dalam peraturan perundang-undangan atau hukum dikonsepkan sebagai kaidah atau norma yang merupakan patokan berperilaku manusia yang dianggap pantas. ${ }^{4}$ Penelitian hukum normatif dilakukan dengan cara meneliti bahan pustaka atau data sekunder belaka. ${ }^{5}$ Penelitian ini (hukum normatif) terdiri dari penelitian terhadap asas-asas hukum, sistematika hukum, taraf sinkronisasi hukum, sejarah hukum dan perbandingan hukum. ${ }^{6}$ Dalam penelitian ini, penulis akan memfokuskan pada asas-asas hukum dan sinkronisasi hukum.

Penelitian hukum normatif akan lebih akurat bila dibantu oleh pendekatan yang cocok guna memperkaya pertimbangan-pertimbangan hukum yang tepat untuk menghadapi problema-problema hukum yang dihadapi, maka pendekatan konsep (Conceptual Approach) lebih tepat digunakan dalam penelitian ini, karena peneliti merujuk pada konsep-konsep dan prinsip-prinsip pemikiran Elly Risman dan konsep perkawinan Islam dalam menelaah pola ketahanan keluarga untuk mencegah kenakalan remaja.

\section{Hasil dan Pembahasan}

\section{Pola Ketahanan Keluarga Untuk Mencegah Kenakalan Remaja Menurut Pemikiran Elly Risman}

Pola ketahanan keluarga menurut Elly Risman ialah berusaha menemukan pokok masalah, berusaha untuk saling terbuka, dan mengerti masa lalu serta pengaruhnya bagi kehidupan sekarang dan masa yang akan datang. ${ }^{8}$ Pola ketahanan keluarga adalah kemampuan keluarga dalam mengelola sumber daya dan masalah yang dihadapinya, untuk memenuhi kebutuhan anggotanya. Ketahanan keluarga terdiri dari tiga hal yakni ketahanan fisik, sosial dan psikologis.

\footnotetext{
${ }^{4}$ Amiruddin dan H. Zainal Asikin, Pengantar Metode Penelitian Hukum, (Jakarta: PT RajaGrafindo Persada, 2013), 118.

${ }^{5}$ Soerjono Soekanto dan Sri Mamudji, Penelitian Hukum Normatif, Suatu Tinjauan Singkat, (Jakarta: PT RajaGrafindo Persada, 2006), 12-13.

${ }^{6}$ Bambang Sunggono, Metode Penelitian Hukum, (Jakarta: PT RajaGrafindo Persada, 2006), 42.

${ }^{7}$ Dalam penelitian hukum ada beberapa pendekatan. Dengan pendekatan tersebut, peneliti akan mendapatkan jawaban dari berbagai aspek mengenai isu yang sedang dicoba untuk dicari jawabnya. Pendekatan-pendekatan yang digunakan di dalam penelitian hukum adalah pendekatan undang-undang (statute approach), pendekatan kasus (case approach), pendekatan historis (historical approach), pendekatan Komparasi (comparative approach), dan pendekatan konseptual (conceptual approach). Peter Mahmud Marzuki, Penelitian Hukum, Edisi Pertama, Cetakan Ke-5, (Jakarta: Kencana Prenada Media Group, 2005), 93.

${ }^{8}$ Elly Risman, Parenting ++1 (Bekasi: The Risman Publishing, 2016), 22.
} 
Elly Risman membahas bagaimana kiat-kiatnya agar kita sebagai pasangan dapat beradaptasi lebih baik dan mampu survive di tengah banyaknya masalah kehidupan yang dihadapi. Ada 8 kiat-kiat yaitu:

a) Karena Allah

Adapun yang terjadi dalam kehidupan perkawinan kita, yang perlu diingat adalah bahwa pernikahan ini melibatkan Allah. Seperti yang lazim disebut orang: pertemuan/jodoh, rezeki dan maut merupakan hak prerogative Allah. Kita tidak akan berjodoh dengan pasangan kecuali dengan izin Allah.

b) Mengenali Diri dan Pasangan

Seperti yang sudah kita bicarakan di tulisan sebelumnya, pengenalan yang utuh tentang proses kehamilan dan pengasuhan diri kita dan pasangan sangat penting untuk diketahui karena dengan begitu kita jadi paham latar belakang pemikiran, sikap dan kebiasaan kita dan pasangan sehari-harinya. Hal yang sangat penting dalam hal ini adalah:

1) Kita belajar menerima diri sendiri dulu, bahwa kita sebagai maanusia ternyata tidak sempurna, maka pantaskah kita berharap pasangan kita sempurna?

2) Kita, sebagaimana juga orang lain tak mungkin steril dari berbagai maslah dalam pengasuhan kita masing-masing. Dengan kata lain kita punya banyak PR dari masa lalu kita/innerchild yang sangat berpengaruh dalam pemikiran, sikap dan kebiasaan kita sehari-hari yang harus kita selesaikan lebih dahulu

3) Dengan pengetahuan tentang masa lalu ini, kita jadi punya perspektif lain tentang pasangan yang bisa meningkatkan rasa cinta, kasihan, rasa ingin menolong dan menunjukkan pengertian sehingga lebih mungkin untuk memaafkan dan berlapang hati terhadap perbedaan-perbedaan dalam berbagai hal. Dengan demikian diharapkan kita bisa "GESER", dari hanya melihat kekurangan, tapi jadi mampu melihat banyak kelebihan yang kita miliki maupun yang dimiliki pasangan kita.

c) Menyelesaikan PR masa lalu (Innerchild) masing-masing.

Apa yang bisa kita lakukan setelah kita menemukan banyaknya masalah emosi dalam gudang bawah sadar kita? Berusahalah memaafkan, meminta ampunan pada Allah siapapun yang telah melakukan hal yang membuat kita menderita, dengan bersungguhsungguh sehingga kita mengapa harus melakukannya?

1) Kalau bukan kita siapa lagi yang bisa memerdekakan pikiran dan hati kita dari semua beban masa lalu tersebut. Untuk mampu menjalani hidup dengan nyaman, lapang dan bahagia kita harus memiliki pikiran dan hati yang merdeka.

2) Kita tidak tahu apa alasan dan tujuan dari orang-orang yang melakukan hal yang buruk terhadap kita tersebut. Apakah mereka melakukannya dengan sadar atau jangan-jangan otomatis saja karena juga mungkin mereka diasuh seperti itu dulunya. Karena semua ini sudah lama terjadi, untuk apa kita mengikatkan diri dan jiwa kita ke masa lalu. Maka putuskanlah serta lepaskanlah.

3) Bukankah kita tidak mau hal yang buruk pada kita terulang pada anak-anak kita? So? Karena sangat pentingya masalah menyelesaikan PR masa lalu ini, kalau anda ternyata tidak sanggup menyelesaikannya sendiri maka saatnya untuk mencari pertolongan ahli.

d) Sadari "kerja" syaithan.

Ingatkan kisah Nabi Adam dan Hawa? Bukankah Syaithan yang menggoda keduanya? 
Karena melanggar ketentuan yang ditetapkan Allah maka keduanya diusir Allah dari Syurga. Bukankah syaithan bersumpah akan menyesatkan kita semua?. Maka, berhatihatilah terhadap kerja syaithan pada kita. Berlindung kepada Allah dan ikhlas adalah cara mengatasi godaan syaithan.

e) Bersyukur

Lihatlah sekeliling kita, berapa banyak orang-orang yang masih berujuang untuk memperoleh jodoh, bahkan pada usia yang hampir telat. Temukanlah bahwa banyak sekali dalam hidup kita ini anugerah Allah yang tiada bertepi, jangan melihat yang negatif saja.

"Seandainya dinding-dinding ruang praktik saya bisa bicara, dia akan bercerita betapa banyak orang yang saya temui menderita dalam perkawinannya, merasakan berbagai hal yang negatif semata-mata karena kurangnya rasa syukur. Dia lupa bahwa bila seseorang bersyukur maka Allah akan menambahkan rahmat dan karunia-Nya, tapi bila seseorang kurang bersyukur, maka yang dirasakannya hanyalah masalah dan kepedihan belaka".

f) Sabar

Ada dua makna tentang "kesabaran": 1) tidak tergesa-gesa, 2) tahan uji dengan penuh keikhlasan. Besar sekali hadiah yang diberikan Allah pada orang-orang yang sabar didunia maupun diakhirat. Maka marilah kita belajar ridha atas apa yang ditakdirkan Allah, karena hanya Allah yang tahu dengan sebenarnya apa yang patut bagi kita. Syurga tidak murah. Kalau tanpa diuji, bagaimana Allah tahu tahu kita ini sabaran atau tidak dan sejauh mana kita menginginkan-Nya serta apakah pantas atau tidak kita masuk Syurga-Nya.

g) Perbaiki komunikasi

Mencoba memperbaiki komunikasi seperti yang sudah dibahas ditulisan yang lalu. Patuh dan gunakanlah cara komunikasi yang telah diperinthkan Allah: bicara baik-baik, bicara dengan kasih sayang, bicara dengan lemah lembut. Baca bahasa tubuh dan coba menebak, menerima dan mengerti perasaan. Cara ini akan sangat mempermudah komunikasi dan mendekatkan jiwa.

h) Be Positif

Bayangkanlah masa depan yang indah dan bahagia. Otak kita senang akan hal-hal yang positif. Peliharalah semangat hidup dan bayangkan hal-hal yang indah yang akan anda capai bersama pasangan serta anak cucu anda dimasa depan. Bermunajatlah pada Allah dan Perwujudannya.

i) Maaf dan Memaafkan

Memaafkan itu perintah Allah dan jadilah Mulia. Allah yang maha tahu, Dia memerinthkan kita dibanyak ayat untuk berbuat kebajikan dan memaafkan kesalahan orang lain yang menyakitkan hati dan rasa kita. Memaafkan itu kata Allah adalah perbuatan yang Mulia. Tapi sebagai manusia biasa saya paham betul minta maaf pekerjaan mudah, tapi untuk memaafkan dan menjadi mulia itu sangatlah susah.

Banyak sekali pasangan muda tidak memiliki kemampuan mengenai kedua hal ini: Beradaptasi dan Survive. Mereka telah mencoba berbagai cara untuk beradaptasi supaya perkawinan mereka dapat dipertahankan, tapi akhirnya menyerah dan bercerai. Apakah ada pengaruhnya ketidakmampuan dalam beradaptasi dan Survive ini terhadap pola asuh dan perkembangan anak-anak? Tentu saja, ketidakmampuan dalam dua hal tersebut akan menimbulkan suasana di keluarga yang tidak nyaman dan tidak jarang diisi dengan 
ketegangan dan pertengkaran. Kita semua paham akan dampak buruknya bagi anak-anak yang tumbuh dan berkembang dalam situasi yang demikian. Mengapa semua ini terjadi, berikut beberapa faktor penyebab:

a) Faktor Internal

1) Pernikahan Dini

Pernikahan dini merupakan pernikahan yang dimulai pada usia 16 tahun dan diakhiri pada usia 20 tahun atau yang masih bersekolah dan dikategorikan remaja. Sedangkan pernikahan yang ideal adalah wanita 20 tahun ke atas dan laki-laki 25 tahun ke atas.

2) Egosentrisme

Egosentrisme didefinisikan sebagai sifat dan kelakuan yang selalu menjadikan diri sendiri sebagai pusat segala hal. Ditemukan bahwa kecenderungan egosentris telah diperpanjang sampai awal masa dewasa dan bahwa kecenderungan ini juga hadir di tahun-tahun dewasa tengah. Dapat disimpulkan bahwa ciri-ciri egosentrisme adalah, Mementingkan diri sendiri, kurangnya rasa peduli, kurangnya peka terhadap keadaan sosial, merasa dirinya paling benar.

3) Kurangnya Komunikasi

Kurangnya komunikasi diantara anggota keluarga satu sama lainnya dapat menjadi faktor melemahnya ketahanan keluarga. Komunikasi yang baik tentu saja akan menghasilkan hubungan yang baik pula serta meminimalisir terjadinya kesalahpahaman. Namun jika komunikasi yang terjadi didalam keluarga kurang bahkan buruk, tentu saja akan menyebabkan permasalahan yang mana dapat memicu pertengkaran dikemudian harinya.

4) Kurangnya Rasa Perhatian

Memberikan perhatian kepada seluruh anggota keluarga secara tidak langsung akan membuat mereka lebih betah dan senang tinggal di rumah. Namun, jika tidak ada rasa perhatian pada setiap anggota keluarga di dalamnya, maka tentu saja tidak akan ada rasa saling mengerti dan memperhatikan satu sama lainnya.

5) Lebih Mementingkan Pekerjaan

Pekerjaan memang adalah hal yang penting, bahkan jika sampai tidak bekerja maka dapat menyebabkan masalah ekonomi di kemudian harinya. Namun jika anda sampai mementingkan pekerjaan dan mengabaikan keluarga tentu saja akan menyebabkan ketidakharmonisan di dalam keluarga.

6) Kurangnya Keterbukaan

Dalam keluarga tentunya dibutuhkan sharing dan rasa saling keterbukaan satu sama lainnya. Dengan keterbukaan tentunya setiap masalah yang terjadi di dalam keluarga dapat terselesaikan dengan mudah. Sehingga tidak ada salahnya untuk saling terbuka satu sama lainnya tanpa menutupi sesuatu sehingga keharmonisan di dalam keluarga dapat tercipta.

7) Perbedaan Prinsip

Prinsip adalah pokok pemikiran dan perbuatan yang menyebabkan setiap orang memiliki prinsip yang berbeda satu sama lainnya. Karena perbedaan inilah terkadang menimbulkan resiko perdebatan yang menyebabkan ketidakharmonisan di dalam sebuah rumah tangga.

8) Membuat Keputusan Tanpa Berdiskusi

Mengambil sebuah keputusan tanpa berdiskusi ataupun berbicara dengan pasangan dan anggota keluarga lainnya tentunya akan membuat pasangan kurang dianggap 
kehadirannya. Hal inilah yang kemudian secara tidak langsung menyebabkan ketidakharmonisan di dalam keluarga.

9) Munculnya Rasa Bosan

Rasa bosan di dalam hubungan keluarga tentu saja dapat dialami setiap orang. Kebosanan adalah hal yang wajar, namun berbeda bagaimana cara orang menyikapinya. Tugas bagi anggota keluarga untuk menyikapi agar bagaimana rasa bosan tersebut tidak mempengaruhi kebahagiaan di dalam rumah tangga. Sehingga keharmonisan tetap dapat terjaga di dalam keluarga.

b) Faktor Eksternal

1) Ekonomi

Kondisi ekonomi kurang baik menjadi pemicu pertengkaran jika tidak adanya rasa lapang dada dan bersyukur dalam diri suami dan istri beserta anak-anaknya. Di sini peran ayah dalam keluarga sangat penting untuk menyeimbangkan keharmonisan rumah tangga.

2) Lingkungan Keluarga yang Tidak Mendukung

Lingkungan keluarga yang tidak mendukung ialah di mana suasana rumah sering gaduh yang disebabkan oleh suami, istri, anak, mertua ataupun saudara ipar. Kegaduhan itu jika sering terjadi akan menimbulkan perpecahan sehingga merasakan tidak betah dan mencari kesenangan di luar.

3) Kurangnya Nilai-nilai Keagamaan Dalam Keluarga

Nilai-nilai keagamaan adalah pondasi dalam membangun ketahanan keluarga. Rendahnya pengetahuan akan nilai-nilai agama membuat komitmen terhadap implementasi nilai-nilai keagamaan menjadi rendah yang berimplikasi pada ketahanan keluarga.

\section{Dampak Dari Melemahnya Ketahanan Keluarga}

a) Pernikahan Dini

Dampak dari pernikahan dini antara lain:

1) Menimbulkan Depresi Berat

Depresi yang terjadi dapat beragam. Bagi orang berkepribadian introvert maka menyendiri, menjauh dari lingkungan, memendam masalah sendiri menjadi pilihan ketika depresi terjadi. Berbeda dengan individu yang cenderung ekstrovet, mereka akan membicarakan masalah yang dihadapi dan mencoba mencari pelampiasan untuk meredakan kekesalan yang terpendam.

2) Perceraian Karena Pemikiran Yang Belum Matang

Pola pikir yang belum matang dalam menyelesaikan masalah, dapat berujung pada pertengkaran berulang. Akibatnya, perceraian tidak dapat dihindari. Hal ini membuat angka perceraian rumah tangga di Indonesia semakin meningkat. Bahkan, tidak jarang orang tua masih banyak ikut campur ketika anak mereka yang menikah di usia dini mengalami masalah dalam rumah tangga yang berdampak buruk bagi kelangsungan pernikahan si anak. ${ }^{9}$

3) Pendidikan Menjadi Terhambat

Ketergesaan menuruti hawa nafsu untuk memiliki pasangan halal justru bisa menjadi boomerang bagi pelaku pernikahan dini. Pasalnya, pendidikan mereka terhambat. Masa

\footnotetext{
${ }^{9}$ Elly Risman, Parenting ++2(Bekasi: The Risman Publishing, 2017), 97.
} 
depan mereka kehilangan cahaya. Terutama untuk laki-laki yang harus memikirkan cara untuk mencari nafkah dan menanggung anak serta istrinya.

4) Terjadi Kekerasan Dalam Rumah Tangga

Emosi yang masih labil, membuat anak di bawah umur mudah marah dan berusaha mencari pelampiasan dengan melakukan kekerasan terhadap anak maupun istri. Tidak jarang, barang-barang di rumah habis terbanting ketika emosi tengah menguasai. Maka, bisa dikatakan pernikahan untuk anak dibawah umur dapat menjadi pemicu terjadinya kekerasan dalam rumah tangga. Lantaran emosi mereka belum stabil dan masih mudah goyah.

5) Kesulitan Ekonomi Dapat Membuat Anak Terlantar

Orang tua berpikir jika satu anak mereka dilepas dan menjadi tanggung jawab suaminya, maka beban orang tua sedikit terangkat. Namun hal ini justru menjadi beban baru bagi suaminya dan kehidupan pernikahan anak mereka. Akibatnya anak-anak menjadi terlantar dan kurang kasih sayang serta perhatian. Sebab orang tua sibuk mencari nafkah demi memenuhi kebutuhan keluarga yang terus meningkat setiap harinya.

b) Egosentrisme

Ada banyak dampak dari egosentrisme dalam pernikahan. Berikut adalah beberapa di antaranya:

1) Sifat egois akan membuat pasangan mudah tidak menyukai anda.

2) Sifat egois menciptakan perasaan sakit hati dan dendam dalam pernikahan.

3) Sifat egois dapat menyebabkan masalah komunikasi dan masalah pernikahan lainnya.

4) Sifat egois mempengaruhi kebahagiaan dalam pernikahan.

5) Sifat egois mencegah anda dari berpikir tentang pasangan dan pernikahan.

6) Sifat egois mencegah pasangan anda tumbuh bersama dalam pernikahan.

7) Sifat egois mencegah pembangunan kepercayaan dan loyalitas dalam pernikahan.

c) Ketidakharmonisan dalam Keluarga

Ketidakharmonisan keluarga adalah bilamana seluruh anggota keluarga merasa tidak bahagia yang ditandai dengan rasa ketegangan, kekecewaan, dan tidak menerima seluruh keadaan dan keberadaan dirinya. Penyebab keluarga tidak harmonis ialah: faktor ekonomi, kurangnya komunikasi, kurangnya rasa perhatian, lebih mementingkan pekerjaan, kurangnya keterbukaan, perbedaan prinsip, sering membuat keputusan tanpa berdiskusi dan muncul rasa bosan.

\section{Upaya Mepertahankan Keluarga}

a) Memperkuat Ketahanan Ayah-Ibu

Ketahanan terhadap eksistensi keutuhan ayah dan ibu sering diuji berbagai godaan di zaman ini. Bagaimana kita akan berjuang melindungi anak anak kita kalau ayah dan ibu sendiri menghadapi masalah yang seperti tak berujung. Jadi mau tidak mau ayah dan ibu sebelum mampu menjalankan peran 'mengasuh berdua' saya himbau untuk berusaha sekuat tenaga menemukan dulu pokok masalah, berusaha untuk saling terbuka dan mengerti masa lalu dan pengaruhnya bagi kehidupan sekarang. Kita sedang berjuang mempertanggung jawabkan pengasuhan anak kita kepada Allah.

b) Menyicil "Hutang Jiwa” Dan Merumuskan Ulang Tujuan Pengasuhan

Untuk mewujudkan peningkatan kualitas pengasuhan anak kita, tak bisa tidak kita harus berusaha mencicil dulu "hutang hutang jiwa" yang kita buat tak sengaja sepanjang 
pengasuhannya di tahun tahun yang lalu. Ayah ibu harus bekerjasama menutup lubang lubang pengasuhan ini, dengan lebih banyak memberikan perhatian dan kasih sayang, kesempatan untuk bersama, mendengarkan perasaan anak, berdialog tentang kesulitan dan tantangan yang mereka hadapi.

c) Komunikasi yang benar, baik dan menyenangkan

Kemampuan berkomunikasi adalah salah satu kemampuan yang sangat dibutuhkan di masa depan, di mana kini komunikasi tersebut telah sangat diringkas dan di"hemat" dengan adanya perangkat teknologi komunikasi. Tetapi komunikasi tatap muka tak bisa dihilangkan begitu saja dan menjadi hal yang penuh tantangan untuk dilakukan dimasa depan, karena sekarang antar kamar saja anak dan orang tua berkomunikasi lewat WhatsApp atau SMS.

d) Mengajarkan Agama Sendiri

Kita perlu memantau pemahaman dan penerapannya sepanjang kehidupan mereka sehari hari. Ya keimanannya, ibadahnya, amalan hariannya, akhlaknya adalah tanggung jawab utama kita.

e) Mempersiapkan Anak Baligh

Orang tua sudah harus mempersiapkan anak pelan pelan dengan penjelasan yang sederhana apa yang akan dihadapi anak pada masa pubertasnya sejak diatas usia 7 tahun. Dari segi ibadahnya, menjaga tubuhnya, berpakaian, pisahkan tempat tidurnya, pergaulan dengan keluarga maupun teman dan sekitarnya dan berbagai adab hidup lainnya.

f) Bijaklah Berteknologi

Kecenderungan orang tua memberikan gadget dan sosial media semakin marak di usia semakin muda. Ada beberapa kota dan kabupaten tertentu yang persentase pemberian gadget pada anak batita dan balita lebih tinggi dari pada anak SD. Kami kawatirkan hal ini terjadi karena orang tua benar-benar latah, memberikan gadget pada anak karena anak orang lain punya. Tapi lebih menyedihkan lagi kalau pemberian itu karena orang tua tidak mau repot dalam mengurus anak yang aktif, menangis, rewel atau yang lebih parah karena mereka tidak mau terganggu dalam membaca dan membalas pesan-pesan teman dari berbagai grup yang dia miliki.

\section{Pola Ketahanan Keluarga Untuk Mencegah Kenakalan Remaja Menurut Konsep Perkawinan Islam}

a. Pengertian Pola Ketahanan Keluarga

Pola ketahanan keluarga adalah konsep dalam menjaga rumah tangga islami dari nilainilai liberalisasi dan sekuler yang dapat mengancam eksistensi keluarga tersebut dalam mengamalkan nilai-nilai yang islami. Setiap keluarga wajib memperkuat ketahanan keluarganya masing-masing.

b. Urgensi Berkeluarga

Dalam sebuah riwayat menyebutkan bahwa ketika Adam masih sendirian diawal kehidupannya ia merasa kesepian ${ }^{10}$, maka Allah menciptakan teman berlawan jenis, hawa, yang kemudian menjadi istrinya. Dari sepasang manusia inilah kemudian berkembang biak menjadi keluarga-keluarga baru lalu menyebar ke suluruh bumi.

c. Tujuan Berkeluarga

\footnotetext{
${ }^{10}$ Departemen Agama RI, Membangun Keluarga Harmoni (Tafsir Al-Qur'an Tematik) (Jakarta: Departemen Agama RI, 2008), 1.
} 
Pernikahan merupakan pemenuhan tujuan Tuhan agar dari pernikahan itu melahirkan keturunan. Sebab pernikahan dalam kacamata Islam merupakan perisai suci untuk menghalalkan laki-laki dan perempuan melakukan hubungan seksual sehingga mereka tidak terjerumus ke dalam perbuatan tercela. Adapun tujuan daripada pernikahan tersebut adalah untuk melahirkan keturunan, mencintai, mendukung, menghibur, menuntun, mendidik, menolong dan menemani.

d. Hikmah Berkeluarga

Islam mengajarkan dan menganjurkan nikah karena akan berpengaruh baik bagi pelakunya sendiri, masyarakat dan seluruh umat manusia.

e. Hak Dan Kewajiban Anggota Keluarga

Undang-Undang Nomor 1 Tahun $19744^{11}$ juga menjelaskan hak dan kewajiban anggota keluarga, sebagai berikut:

Hak Dan Kewajiban Suami Isteri

Pasal 30

Suami isteri memikul kewajiban yang luhur untuk menegakkan rumah tangga yang menjadi sendi dasar dari susunan masyarakat.

Pasal 31

1) Hak dan kedudukan isteri adalah seimbang dalam kehidupan rumah tangga dan pergaulan hidup bersama dalam masyarakat.

2) Masing-masing pihak berhak untuk melakukan perbuatan hukum.

3) Suami adalah kepala keluarga dan isteri ibu rumah tangga.

Pasal 32

1) Suami isteri harus mempunyai tempat kediaman yang tetap.

2) Rumah tempat kediaman yang dimaksud dalam ayat (1) pasal ini ditentukan oleh suami isteri bersama.

Pasal 33

Suami isteri wajib saling cinta-mencintai, hormat-menghormati, setia dan memberi bantuan lahir batin yang satu kepada yang lainnya.

Pasal 34

1) Suami wajib melindungi istrinya dan memberikan segala sesuatu keperluan hidup berumah tangga sesuai dengan kemampuannya.

2) Isteri wajib mengatur urusan rumah tangga sebaik-baiknya.

3) Jika suami atau isteri melalaikan kewajibannya masing-masing dapat mengakibatkan gugatan ke Pengadilan.

Hak Dan Kewajiban Antara Orang Tua Dan Anak ${ }^{12}$

Pasal 45

1) Kedua orang tua wajib memelihara dan mendidik anak-anak mereka sebaik-baiknya.

2) Kewajiban orang tua yang dimaksud dalam ayat (1) pasal ini berlaku sampai anak itu kawin atau dapat berdiri sendiri, kewajiban mana berlaku terus meskipun perkawinan antara kedua orang tua purus.

Pasal 46

1) Anak wajib menghormati orang tua dan mentaati kehendak mereka yang baik.

\footnotetext{
${ }^{11}$ Undang-undang Perkawinan, UU No 1 Tahun 1974 (Surabaya: Pustaka Tinta Mas),87-89.

${ }^{12}$ Undang-undang Perkawinan, UU No 1 Tahun 1974 (Surabaya: Pustaka Tinta Mas), 91-92.
} 
2) Jika anak telah dewasa, ia wajib memelihara menurut kemampuannya, orang tua dan keluarga dalam garis lurus ke atas, bila mereka itu memerlukan bantuannya.

Pasal 47

1) Anak yang belum mencapai umur 18 (delapan belas) tahun atau belum pernah melangsungkan perkawinan dibawah kekuasaan orang tuanya selama mereka tidak dicabut dari kekuasaannya.

2) Orang tua mewakili anak tersebut mengenai segala perbuatan hukum didalam dan di luar Pengadilan.

Pasal 48

Orang tua tidak diperbolehkan memindahkan hak atau menggadaikan barang-barang tetap yang dimiliki anaknya yang belum berumur 18 (delapan belas) tahun atau belum pernah melangsungkan perkawinan, kecuali apabila kepentingan anak itu menghendakinya.

Pasal 49

1) Salah seorang atau kedua orang tua dapat dicabut kekuasaannya terhadap seorang anak atau lebih untuk waktu yang tertentu atas permintaan orang tua yang lain, keluarga anak dalam garis lurus ke atas dan saudara kandung yang telah dewasa atau pejabat yang berwenang, dengan keputusan Pengadilan dalam hal-hal:

a) Sangat melalaikan kewajibannya terhadap anaknya;

b) Berkelakuan buruk sekali.

2) Meskipun orang tua dicabut kekuasaannya, mereka masih tetap berkewajiban untuk memberi biaya pemeliharaan kepada anak tersebut.

f. Faktor-Faktor Yang Diperlukan Dalam Ketahanan Keluarga

Agar nikah (penyatuan) dan zawaj (berpasangan) itu langgeng lagi diwarnai oleh sakinah, agama menekankan sekian banyak hal antara lain:

a) Kesetaraan

Kesetaraan ini mencakup banyak aspek, seperti kesetaraan dalam kemanusiaan. Tidak ada perbedaan dari segi asal kejadian antara lelaki dan perempuan. Sekian kali kitab suci Al-Qur'an menegaskan bahwa ba'dhukum min ba'dh (sebagian kamu dari sebagian yang lain).

b) Musyawarah

Pada saat bermusyawarah atau berkomunikasi, banyak sekali tuntutan dan tata cara yang diajarkan agama, mulai dari sikap batin dan kesediaan memberi maaf, kelemahlembutan dan kehalusan kata-kata, sampai kepada ketekunan mendengar mitra musyawarah.

c) Kesadaran Akan Kebutuhan Pasangan

Kebutuhan tersebut banyak dan beraneka ragam tidak hanya dalam bidang jasmani atau seks, tetapi juga rohani sedemikian banyak hingga dia tidak putus-putusnya. Begitu kebutuhan tersebut tidak dirasakan lagi, ketika itu pula cinta memudar dan pernikahan goyah.

g. Mengelola Konflik Dan Membangun Ketahanan Keluarga

Konflik dalam keluarga terjadi karena berbagai persoalan. Misalnya, karena pasangan merasa tidak terpenuhi kebutuhannya, hubungan yang tidak setara, perbedaan budaya, peran dan tanggungjawab. Prinsip menyelesaikan masalah tersebut adalah dengan $m u$ "asyaroh bil $m a$ "ruf yaitu memperlakukan pasangan dengan sopan. Sebagaimana prinsip dalam 
perkawinan adalah saling melengkapi dan melindungi. Maka dalam hal ini dibutuhkan keterampilan/teknik dan cara mengelola konflik dengan baik.

a) Mengelola Perbedaan

Perbedaan yang kadang kala menimbulkan konflik tidak perlu dihindari tetapi justru perlu dikelola sehingga persoalan yang dihadapi selesai dengan baik. Konflik yang dihindari justru akan menjadi tumpukan masalah yang resikonya mengganggu relasi rumah tangga semakin besar di kemudian hari.

Sumber-Sumber Konflik

Masalah rumah tangga merupakan masalah bersama yang harus dibicarakan dengan baik di antara suami isteri. ${ }^{13}$ Penyelesaian masalah akan mudah dilakukan jika relasi suami isteri dikondisikan setara, bebas dari dominasi dan diskriminasi atas dasar perbedaan gender.

Adapun bentuk masalah yang menghambat relasi suami isteri dalam rumah tangga, antara lain:

1) Cemburu

Cemburu merupakan perasaan yang tidak menyenangkan terhadap pasangan baik suami atau isteri atas perbuatannya karena dianggap mengabaikan bahkan merampas hak-hak pasangannya. Dalam hal ini dalam bentuk cinta, kasih sayang, dan perhatian yang dipandang hilang atau berkurang dari pasangannya.

2) Ekonomi

Salah satu modal dasar seorang berumah tangga adalah tersedianya sumber penghasilan yang jelas untuk memenuhi kebutuhan hidup secara finansial. Kelangsungan hidup keluarga antara lain ditentukan oleh kelancaran ekonomi, sebaliknya kekacauan dalam keluarga dipicu oleh ekonomi yang kurang lancar.

3) Manajemen Waktu Dan Pergeseran Peran Gender

Dalam kaitannya dengan aktivitas mencari nafkah dan kegiatan sosial lainnya yang dilakukan oleh suami isteri maupun anggota keluarga. Intensitas pertemuan dalam keluarga perlu dikelola sedemikian rupa. Sehingga tidak semua waktu tersita dan terkonsentrasi pada satu jenis kegiatan. Manajemen waktu menjadi sangat urgen dan berarti, apalagi ketika suami isteri sama-sama bekerja di luar rumah, sementara pekerjaan reproduksi dalam rumah tangga tidak dapat diabaikan. Ketidak mampuan mengatur jadwal kerja baik publik maupun domestik akan berakibat pada beban berlipat dalam pekerjaan dan kurangnya kesempatan untuk saling mencurahkan perasaan antar anggota keluarga.

4) Orang ketiga

Keharmonisan keluarga dapat sirna ketika terjadi intervensi pihak ketiga. Tidak hanya masalah ekonomi yang tidak baik, tapi jauh lebih parah adalah hilangnya saling rasa percaya, kasih sayang dan keharmonisan rumah tangga. Perselingkuhan merupakan bentuk kekerasan psikis yang biasanya diikuti kekerasan lain seperti kekerasan fisik, ekonomi dalam bentuk penelantaran keluarga. Kekerasan psikis sebagai dampak dari kehadiran pihak ketiga merupakan bentuk pencideraan terhadap komitmen perkawinan yang lebih parah dibandingkan dengan kekerasan psikis lainnya.

b) Manajemen Konflik

\footnotetext{
${ }^{13}$ Mufidah, Psikologi Keluarga Islam Berwawasan Gender (Malang: UIN-MALIKI PRESS, 2013), 176.
} 
Dalam mengelola konflik dan tantangan keluarga sebisa mungkin direspon dengan cara yang arif sehingga bisa menjadi batu ujian bagi keluarga untuk semakin tangguh. Namun demikian jika memerlukan pertolongan pihak lain, maka sebaiknya menghubungi lembaga-lembaga pemberi layanan konseling, advokasi hukum dan penyelesaian masalah-masalah yang terkait.

\section{Komparasi Pemikiran Elly Risman dan Konsep Perkawinan Islam dalam Pola} Ketahanan Keluarga untuk Mencegah Kenakalan Remaja

a) Pola Ketahanan Keluarga untuk Mencegah Kenakalan Remaja Menurut Pemikiran Elly Risman

1) Elly Risman adalah seorang psikolog keluarga maka beliau mengedepankan perasaan dan dampak yang akan terjadi dalam psikisnya. Di mana menurut elly risman hancurnya keluarga itu berasal dari adanya sakit hati antara kedua belah pihak. Dari hal kecil ini akan menimbulkan masalah yang sangat besar di masa yang akan datang.

2) Pemikiran Elly Risman mengedepankan ketahanan keluarga yang akan berdampak kepada pertumbuhan seorang anak. Jika rumah tangga tidak utuh maka akan ada dampak yang sangat besar karena ketidakutuhan dalam pengasuhan akan sangat berpengaruh kepada pertumbuhan anak. Elly Risman mengatakan bahwa, orang tua memiliki peran penting dalam proses pertumbuhan atau perkembangan seorang anak. "Jika anak kurang kasih sayang ayah, ayah tidak dekat dengan anak, emosi anak akan terganggu. Kalau laki-laki cenderung akan nakal, seks bebas, dan narkoba, sedangkan anak perempuan akan depresi dan melakukan seks bebas".

b) Pola Ketahanan Keluarga Untuk Mencegah Kenakalan Remaja Menurut Konsep Perkawinan Islam.

1) Mengingat Tujuan Berkeluarga

Pada saat ingin membina keluarga, maka dari pasangan suami-istri harus memiliki tujuan yang sama. Di mana tujuan tersebut mengedepankan kenyamanan antar anggota keluarga, agar setelah menikah dapat menjalankan tujuan yang telah disepakati di awal pernikahan

2) Mengedepankan Hak dan Kewajiban Anggota Keluarga

Kokohnya ketahanan keluarga ialah dimulai dari kesadaran antar anggota keluarga atas kewajibannya. Selain itu antar keluarga juga harus mampu memahami hak dari anggota keluarga lainnya. Dengan demikian maka tidak akan terjadi kesenjangan antara anggota keluarga.

3) Memperhatikan Kesetaraan (Keturunan, Agama, Budaya, Pendidikan dan Usia)

Kesetaraan dalam perkawinan merupakan faktor yang dapat mendorong terciptanya kebahagiaan suami isteri, dan lebih menjamin keselamatan perempuan dari kegagalan atau kegoncangan rumah tangga.

c) Persamaan Dari Pemikiran Elly Risman dan Konsep Perkawinan Islam.

1) Memperkuat Nilai-nilai Keagamaan

Sebelum terjadi pernikahan setiap manusia harus menanamkan nilai-nilai keagamaan yang sangat matang. Karena sebelum menjadi orang tua maka dari ayah dan ibunya dulu lah yang menanamkan keimanan serta ketakwaan. Anak akan meniru segala gerak gerik orang tuanya, maka tanamkan keimanan dan ketakwaan sedini mungkin.

2) Mengutamakan Adanya Komunikasi (musyawarah) dan Keterbukaan 
Pernikahan yang melahirkan mawaddah dan rahmat adalah pernikahan yang di dalamnya kedua pasangan mampu berdiskusi menyangkut segala persoalan yang mereka hadapi, sekaligus keluwesan untuk menerima pendapat dari pasangannya.

3) Menumbuhkan Rasa Perhatian dan Sadar Akan Kebutuhan Pasangan

Dalam rumah tangga perhatian antar pasangan memegang peran penting, karena munculnya rasa nyaman dan cinta kasih itu berawal dari perhatian. Dan jika kita sadar akan kebutuhan pasangan maka pasangan juga akan melakukan hal yang sama.

4) Mencari Solusi Ketika Rumah Tangga Mulai Goyah

Ketika ada masalah kita harus mampu mengelola permasalahan bukan meninggalkan permasalahan. Karena rumah tangga akan hancur jika kita membiarkan masalah terus menerus. Maka dengan ini kita harus mampu mengelola sampai mendapatkan solusi.

\section{Kesimpulan}

Peraturan Di Jawa perkawinan menjadi pertanda terbentuknya somah baru yang segera akan memisahkan diri, baik secara ekonomi, maupun tempat tinggal, lepas dari kelompok orang tua dan membentuk sebuah basis untuk sebuah rumah tangga baru. Akan tetapi dalam nyatanya sebagaimana yang terjadi pada masyarakat mayang bahwa peranan orang tua terhadap anaknya yang telah berkeluarga masih ada. Hal ini terbukti dengan adanya beberapa intervensi orang tua dalam rumah tangga anak yang meliputi permasalahan materi yang terbentuk dari penentuan tempat tinggal dan nafkah tambahan. Begitupun juga permasalahan dalam inmateri yang mencakup dengan nasehat terhadap permasalahan keluarga anak yang belum dapat terselesaikan dan meminta orang tua untuk membantu menyelesaikannya.

\section{Daftar Pustaka}

\section{Buku:}

Al-Nabawi, 2006, Khadijah al-Nabawi, mausu'ah Huquq al-Insan fi al-Islam, Mesir : Dar Alsalam

Anwar, Syamsul, 2007, Studi Hukum islam Kontemporer, Jakarta: RM Books

As'ad, Abdul Muhaimin, 1993, Risalah nikah penuntun perkawinan, Surabaya: Bintang Terang99

Adhim, Mohammad Fauzil, 2012, Mencapai pernikahan barokah, yogyakarta: Mitrapustaka

Al-Muslim, Al-Bukhori, 2011, Ensiklopedia Hadist Shahih al-bukhori 1, terjemah Masyhar dan Muhammad Suhadi, Jakarta:Almahira Cet-1

Basyir, Ahmad Azhar, 1983, Hukum Adat Bagi Umat Islam, Yogyakarta: Nur Cahaya.

Basri, Hasan, 1996, Merawat Cinta Kasih, Yogyakarta : Pustaka Pelajar

Bastaman, H.D., 1996, Meraih Hidup bermakna kisah pribadi dengan pengalaman tragis, Jakarta:Paramadina

Bakry, Sidi Nazar ,1993, kunci keutuhan Rumah Tangga, Jakarta: Pedoman Jaya

Kuswara,1991, Teori-Teori Keperibadian, Bandung: Eresco, cet.ke-2

Dr.H.Hasbiyallah, M.Ag, 2015, keluarga sakinah, Bandung:PT Remaja Rosdakarya

Djamil, M.Nasir, 2013, Anak Bukan untuk dihukum, Jakarta : Sinar Grofika

Departemen Pendidikan dan Kebudayaan, 1990, Kamus Besar Bahasa Indonesia, Jakarta: Balai Pustaka

Daradjat, Zakiah, 2012, , Ilmu Pendidikan Islam, jakarta: bumi aksara

Departemen agama, 1993, Kamus Besar Bahasa Indonesia , Jakarta: Balai pustaka 
Faridh, Miftah, 1983, Keluarga Bahagia, Bandung : Pustaka

H. Hendri, 2000, Pengantar Studi Sosiologi Keluarga, Bandung : CV Pustaka Setia

Hasbullah, 2011, Dasar-dasar Ilmu Pendidikan, Jakarta: Raja Grafindo, 2011

Hadikusumo Hilman,1995, Hukum Perkawinan Adat, Bandung:PT Cipta Bakti

IAIN Jember,2017, Pedoman Penulisan Karya Ilmiah, Jember: IAIN Jember Press

IAIN Jember,2018, Pedoman Penulisan Karya Ilmiah, Jember: IAIN Jember Press

J'Moleong, Lexy, 2011, Metode Penelitian Kualitatif, Bandung: PT Remaja Rosdakarya

Masyhuri, Sayyid Abi Bakr Al, 1992, Al-Ianah At-Talibin, Semarang: Toha Putra

Muchtar, Kamal, 1974, asas-asas hukum islam tentang perkawinan, Jakarta: Bulan Bintang

Mustakim, Abdul, 2006, kedudukan dan hak-hak anak dalam perspektif Al-Qur'an, , Artikel, jurnal Musawa, Vol.4 No.2

Nasution, Bahder, 2016, Metode Penelitian Ilmu Hukum, Bandung : CV Mandar Maju

Nasution, Khoiruddin,2011, Hukum Keluarga (Perdata) Islam Indonesia, Yogyakarta : ACA de MIA + Tazzafa

Purwanto, M. Ngalim, 2009, Imu Pendidikan Teoritis dan Praktis, Bandung: PT Remaja

Roqib, Moh, 2011, Ilmu Pendidikan Islam, Yogyakarta: LKS Group

Sugiyono,2011, Metode Penelitian Kuantitatif, Kualitatif dan RED, Bandung: Alfabeta

Suhendi, Hendi, 2001, , Pengantar Studi Sosial Keluarga, Bandung : Pustaka Setia

Sutopo, 2002, Metodelogi Penelitian kualitatif, Surakarta: sebelas maret university press

Soelaeman, M.Munandar,1989, Ilmu Sosial Dasar, Teori dan Konsep Ilmu Sosial,Bandung: PT ERESIO Bandung

Thalib, Sayuti,1986, Hukum kekeluargaan Indonesia, cet, ke-5, Jakarta: Universitas Indonesia Uhbiyati, Nur, 2013, Dasar-dasar Ilmu Pendidikan Islam, semarang: pustaka Riski Putra

\section{Peraturan Perundang-undangan:}

UU Nomor 1 Tahun 1974 tentang Perkawinan,

Undang-Undang Republik Indonesia Nomor 23 Tahun 2002 tentang Perlindungan Anak 